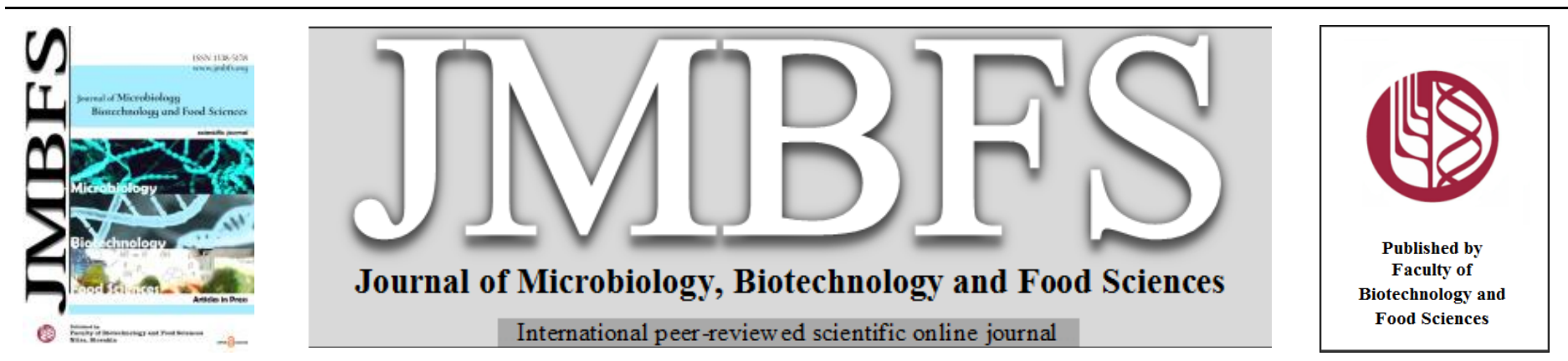

\title{
POSSIBILITY OF IPA BEER PRODUCTION, AND ITS COMPARISON WITH THE STANDARD BREWERY BEER IN "BIRRA PEJA", IN PEJA
}

\author{
Arsim Elshani ${ }^{1}$, Nexhdet Shala ${ }^{*}$, Ibrahim Hoxha $^{1}$, Kastriot Pehlivani $^{2}$ \\ Address(es): \\ ${ }^{1}$ Departament of Food Technology, Agribusiness Faculty, University of Haxhi Zeka, Peja, Kosovo. \\ ${ }^{2}$ Department of Food Technology, UBT Collogue, Pristina, Kosovo.
}

*Corresponding author: nexhdet.shala@unhz.eu

\section{ARTICLE INFO}

Received 15. 7. 2021

Revised 29.1. 2022

Accepted 31. 1.2022

Published 1. 6. 2022

Regular article OPEN $\partial_{\text {ACCESS }}$

\begin{abstract}
Based on management requirements for innovation and following the global trend with new beers, we have tried to do our best for a beer that has never been in our products before. To produce this new beer with us at the Birra Peja brewery, we used the same malt as for the production of our current and best-selling beer, light beer, known as pilsner. To have an acceptable result, we used special Roasted malt with pronounced aroma characteristics. We also went in combination with our usual malt for the production of pilsner beer. Malt baked by a special production procedure has a reddish sheen and typical aroma, which serves to intensify and stabilize the aroma. And we used four different hops, Aurora, Ella, Cascade, and Palisade, which are used in certain stages of production to give the required fat for this type of beer. Also, in fermentation, we used special Fermentis yeast of type safale T58, to make India Pale Ales (IPA) or our brand "IPA Peja".

For this type of beer is used the method of European brewery convection EBC. During boiling, hops with pronounced characteristics for this type of beer are added to achieve the right amount of fat. After maturing, we filtered this beer in the candle filter with only one Hyflo cel coating.
\end{abstract}

Keywords: Beer, fermentation, hops, IPA, malt, yeast

\section{INTRODUCTION}

For the production of IPA beer, the necessary preparations have been made, first to ensure the conditions of this type of beer, starting with the collection of the necessary raw material and the creation of space for production (Liguori and De Francesko 2020). The production is made in the amount of $320 \mathrm{Hl}$, because that is a boiling charge, and the usual production technology is used, but with the change of some ingredients and with another method of fermentation, in this part of the beginning of the production of ordinary malt for the production of pilsner beer as a standard beer of Peja Beer, we have added black malt to characterize this beer, and we have added corn flour, while after the end of boiling in the whirlpool we have added Sapphire and Palisade hops of $5 \mathrm{~kg}$ (Kunze and Manger 2004). Since for fermentation, we have used special yeast from the manufacturer Fermentis such as type safale T-58, for this type of beer (Gonçalves Bortoleto and Pinheiro Claro Gomes 2021). Specialty brewer's yeast was selected for its strong fermentation character, intensely fruity and phenolic flavors - especially banana, clove, and peppery notes. Suitable for a great variety of wheat-based beers and fruity-spicy-oriented styles (Oghenetega et al., 2021).

IPA beer has undergone all laboratory controls at different stages of production, starting from boiling, fermentation, Maturation, filtration, and filling (Zainasheff and White 2010). It is worth mentioning that at the end of maturity, after 21 days, we have tasted IPA beer, and the tasting group and the sales department have decided to filter this beer and fill it for the market, as it meets all the conditions to be a beer competitive (Bonatto 2021).

In the analysis of ready-made beer, we notice an increase in fermentation slightly larger than it should be, a greater amount of alcohol compared to standard beer, and more color in the beer (MEBAK 2017) (Barnes 2006).

According to the literature, Peja IPA beer should have a value of visible fermentation rate below $80 \%$, respectively $74-78 \%$. Still, we have won a beer with a higher percentage of visible fermentation rate, $78.7 \%$ (EBC 2019).

It is worth mentioning that we have managed to have a bitter beer with a characteristic color of IPA-type beer. According to the Central European Brewery Analysis Commission, this competitive beer has been produced for the market, adhering to all the required quality conditions and, according to the Central European Brewery Analysis Commission (in German: Mitteleuropäische Brautechnische Analysenkommission), MEBAK ${ }^{\circledR}$ standards (López et al., 2020).

\section{MATERIALS AND METHODS}

\section{Cooking}

For brewing, standard malt was used for the production of light beer in the amount of $2750 \mathrm{~kg}$, we also added caramel malt in the amount of $1000 \mathrm{~kg}$ with EBC 700 due to the addition of beer color, and we used cornflour in the quantity of $1550 \mathrm{~kg}$. (Loredana Liguori 2021) (Kunze and Manger 2004) in this amount of malt and flour we added water in the amount of 18000 litters. It is worth mentioning that for better filtration in the sweet solution filters, we have added Ultra flow max enzymes in the amount of $300 \mathrm{ml}$, and for the decomposition of the starch, we have used termamyl enzymes in the amount of $500 \mathrm{ml}$. After grinding for $\mathrm{pH}$ adjustment, we added 6 liters of lactic acid (Benitez 1997). At the same time, the cooking procedure has been with two decoctions, same as standard beers.

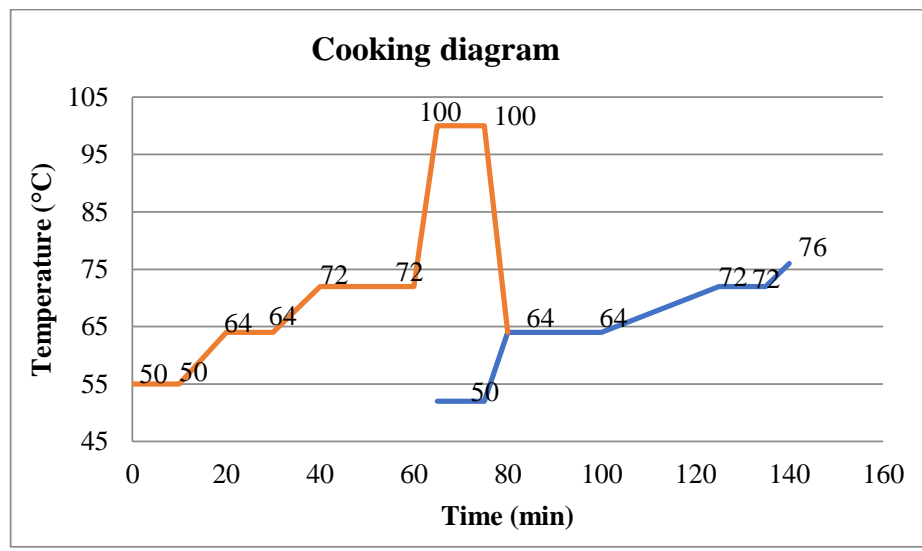

Figure 1 Cooking diagram with the decoction

Also, in the decoction, we have added $4 \mathrm{~kg}$ of hops in the first dose and $10 \mathrm{~kg}$ of hops aurora in the second dose, while in the whirlpool, we have before filled with 
the sweet solution, placed the Perle and Saphir hops from $5 \mathrm{~kg}$ (EBC 2008). And then, this mass of sweet solution in the amount of 31000 liters is transferred to a cylindrical cone fermenter, where along the way, we have added the yeast prepared in advance for this type of beer.

\section{Fermentation}

The choosing of extract, visible extract, real extract, visible fermentation, alcohol on $\mathrm{mg} / \mathrm{l}$, alcohol volumetric $\mathrm{v} / \mathrm{v}$, and spreading. A few measurements are made with a beer analyzer (Anton PAAR) (EBC 2019).

For the fermentation, there is given an amount of oxygen of $8 \mathrm{mg} / \mathrm{lit}$, also some enzymes of Fungamyl and Maturex on an amount of $500 \mathrm{ml}$. While on the standard beer, we give yeast of Saccharomyces carlsbergensis on an amount of $20 \mathrm{Hl}$ on fermentation, on IPA Peja beer is given yeast of Fermentis type safale T-58 in the amount of 6000 litters, which is before use is prepared.

The boiling of the sweet solution continued according to the given recipe and was completed successfully. In figure no. 1, below, we present the way of brewing IPA beer (Bamforth 2010).

As mentioned above, for the fermentation of this type of beer, the yeast of the manufacturer Fermentis, type safale $T-58$. The primary fermentation lasted six days. In figure no. 2, we can see that the fermentation went well without any delay, and figure 3 shows the fermentation of pilsner Peja standard beer. Then after this time, the new beer is sent to the Maturation of beer.

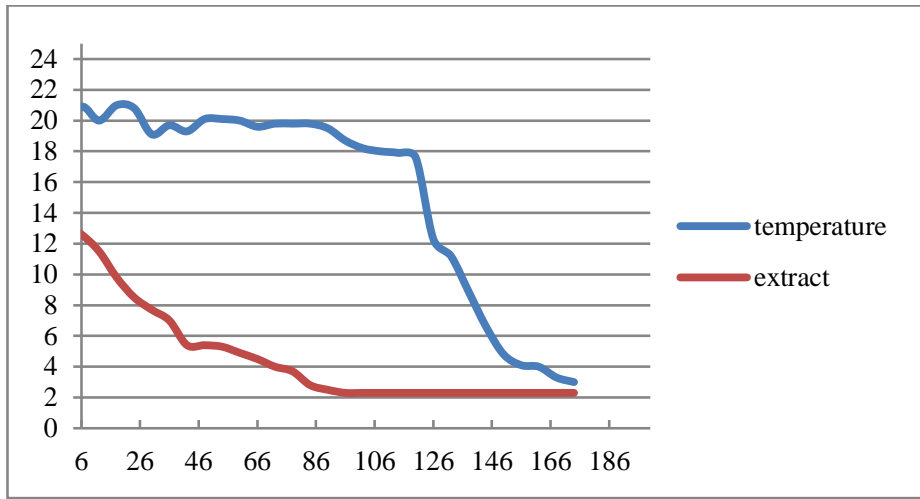

Figure 2 Primary fermentation of Peja IPA beer

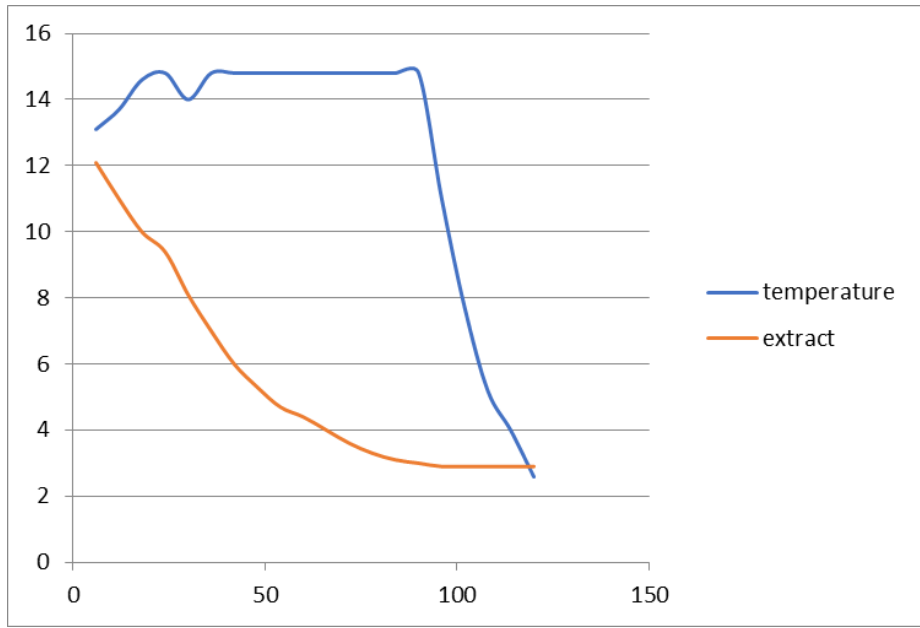

Figure 3 Primary fermentation of Peja pilsner standard beer Preparations of yeast on beer IPA PEJA

It was known that the primary duty of propagation of the yeast is to make yeast for dosing with correct metabolism and as fast as possible, under sterile conditions (Zainasheff and White 2010). It's taken wort, and it is put on an inox dish cleaned beforehand, and on it, it's been put yeast of type Fermentis safale T-58 on an amount of $1.0 \mathrm{~kg}$ dry yeast, it is left like that at a temperature of $22^{\circ} \mathrm{C}$ on the purpose of making the hydration of the yeast. Then after every hour, the yeast has been mixed and recycling every hour in 2 minutes in a tank for yeast propagation. Then after 6 hours of sweet dip on an amount of $20 \mathrm{Hl}$, we put it on the proliferation reservation of yeast, and we recycle every 2 hours, in 2 minutes. Pressure and temperatures are growing a little (Hough and Brigs 2004). After 24 hours, we have added the following $30 \mathrm{Hl}$ of sweet dip, and we are recycling again.

After 24 hours of filling a cylindrical cone fermentation tank with sweet dip on an amount of $315 \mathrm{Hl}$, we give the yeast prepared on an amount of $50 \mathrm{Hl}$. Now we have in on the fermentation in a total of $365 \mathrm{Hl}$ beers, and with this, begin the fermentation of IPA PEJA beer.

\section{The fermentation procedure of IPA PEJA beer}

We keep the fermentation on a pressing of a 0.2 bar temperature at $24^{\circ} \mathrm{C}$ until the extract is down to $4 \%$. After that, we have taken new beer from CKT in the amount of $70 \mathrm{Hl}$, and we have put in a special kettle. Before filling this special kettle, we have put hops inside in amounts: $20 \mathrm{~kg}$ Palisade, Chinook $20 \mathrm{~kg}$, and $20 \mathrm{~kg}$ Ella.

The rest beer in CKT, the now in amount of $295 \mathrm{Hl}$, we close $\mathrm{CO}_{2}$ on 1 bar after extract is down in 2.2, and the fermentation ends we keep it like that for another 24 hours on 1 bar and at a temperature of $22^{\circ} \mathrm{C}$ and then we cool it down to $-1{ }^{\circ} \mathrm{C}$ (Kunze and Manger 2004).

In this special tank, the now where we have $70 \mathrm{hl}$ of beer with hops, we make a dry hoping, like the next three days, we take the pressure in 0.8 bar, temperature around $20-22^{\circ} \mathrm{C}$, and we recycle every 2 hours for $5 \mathrm{~min}$. Then, after three days, we started to put away sedimented yeast for the next day. So, we have put this beer in CKT when we have taken it before, and now, we have around $355 \mathrm{hl}$ new or green beer (Charles 2003)

After it's cooled down, we take away the yeast from the newly made beer and transport it on fermentation for maturing.

\section{Beer maturation}

We make the beer maturation on a pressing of 1 bar and a temperature of $-1{ }^{\circ} \mathrm{C}$ After the Maturation of 20 days a bit before the filtration, we remove the sedimented yeast and filter it with the Filtrox filter using diatomic- kieselguh (EBC 2019). We put the filtered beer on an under-pressure tank, and then we placed it on the filling part to be filled.

\section{RESULTS AND DISCUSSION}

In table no. 1, are given the values obtained from the standard beer Peja, as well as IPA. We notice that we have significant changes in the data, as is the case in color IPA has a higher value, and at $\mathrm{pH}$, IPA has a lower value.

Table 1 Chemical analysis of wort

\begin{tabular}{lccccc}
\hline $\begin{array}{l}\text { Type of } \\
\text { beer }\end{array}$ & $\begin{array}{c}\text { Extracts in the } \\
\text { laboratory }\end{array}$ & Colour & $\begin{array}{c}\mathrm{pH} \\
\text { value }\end{array}$ & Bitterness & Density \\
\hline $\begin{array}{l}\text { Standard } \\
\begin{array}{l}\text { Birra } \\
\text { Peja }\end{array}\end{array}$ & 11.54 & 6.7 & 5.34 & 33 & 1.0523 \\
\hline IPA Peja & 11.84 & 24.3 & 4.98 & 31 & 1.0434 \\
\hline
\end{tabular}

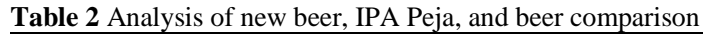

\begin{tabular}{|c|c|c|c|c|c|c|c|c|c|}
\hline 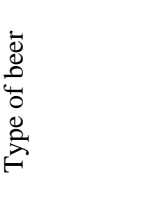 & 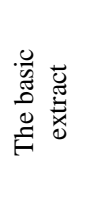 & 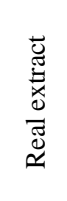 & 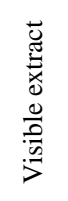 & 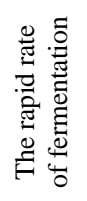 & 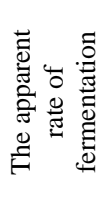 & $\begin{array}{l}\frac{1}{3} \\
0 \\
0 \\
0 \\
\frac{0}{8} \\
\frac{0}{4}\end{array}$ & $\begin{array}{l}\Xi \\
\Xi \\
0 \\
0 \\
0 \\
\frac{0}{0} \\
\frac{0}{2}\end{array}$ & 竞 & $\frac{\dot{0}}{0}$ \\
\hline Standard & 11.54 & 4.17 & 2.06 & 69.50 & 82.22 & 5.72 & 4.47 & 4.39 & 8.3 \\
\hline IPA Peja & 11.84 & 3.88 & 1.81 & 71.13 & 86.18 & 6.03 & 4.74 & 4.34 & 22.3 \\
\hline IPA Peja & 11.79 & 3.85 & 1.79 & 71.69 & 86.20 & 5.95 & 4.55 & 4.23 & 21.1 \\
\hline IPA Peja & 11.80 & 3.97 & 1.93 & 68.43 & 81.64 & 6.02 & 4.73 & 4.32 & 22.4 \\
\hline
\end{tabular}

We notice from table no. 2 that we have a visible extract lower than the standard one. Also, the amount of alcohol and color is slightly bigger. On we give the analysis of standard and IPA Peja beer, made after 15 days:
Also, in beer attenuation analyses table no. 3, we notice that we have an increase in the values of the rapid rate of fermentation and apparent rate of fermentation. 
Table 3 Analyses of attenuation of beer, standard, and IPA Peja beer

\begin{tabular}{lccccccc} 
Type of beer & $\begin{array}{c}\text { The basic } \\
\text { extract }\end{array}$ & Real extract & $\begin{array}{c}\text { Visible } \\
\text { extract }\end{array}$ & $\begin{array}{c}\text { The rapid rate of } \\
\text { fermentation }\end{array}$ & $\begin{array}{c}\text { The apparent rate } \\
\text { of fermentation }\end{array}$ & $\begin{array}{c}\text { Alcohol \%, } \\
\text { v/v }\end{array}$ & $\begin{array}{c}\text { Alcohol \%, } \\
\text { m/m }\end{array}$ \\
\hline Standard & 13.04 & 4.17 & 2.06 & 69.50 & 84.15 & 5.87 & 4.60 \\
IPA Peja & 13.09 & 3.97 & 1.81 & 71.13 & 86.20 & 6.03 & 4.73 \\
$\begin{array}{l}\text { 09.12.2016 } \\
\text { IPA Peja }\end{array}$ & 13.25 & 4.01 & 1.82 & 71.17 & 86.22 & 6.11 & 4.79 \\
15.12.2016 & & & & & & \\
\hline
\end{tabular}

On we give the table with beer info for ready beer, standard beer, and IPA Peja beer:

Table 4 Analysis of ready beer, Standard and IPA Peja beer

\begin{tabular}{lllllllllll}
$\begin{array}{l}\text { Type of } \\
\text { beer }\end{array}$ & $\begin{array}{l}\text { The basic } \\
\text { extract }\end{array}$ & $\begin{array}{l}\text { Real } \\
\text { extract }\end{array}$ & $\begin{array}{l}\text { Visible } \\
\text { extract }\end{array}$ & $\begin{array}{l}\text { The rapid rate } \\
\text { of } \\
\text { fermentation }\end{array}$ & $\begin{array}{l}\text { The apparent } \\
\text { rate } \\
\text { fermentation }\end{array}$ & $\begin{array}{l}\text { Alcohol } \\
\%, \mathrm{v} / \mathrm{v}\end{array}$ & $\begin{array}{l}\text { Alcohol } \\
\%, \mathrm{~m} / \mathrm{m}\end{array}$ & $\begin{array}{l}\text { Bitterness } \\
\mathrm{EBC}\end{array}$ & $\begin{array}{l}\mathrm{Colour} \\
\mathrm{EBC}\end{array}$ & $\begin{array}{l}\mathrm{CO} \mathrm{O}_{2} \\
\mathrm{~g} / \mathrm{l}\end{array}$ \\
\hline Standard & 10.72 & 3.46 & 1.83 & 67.89 & 82.56 & 4.56 & 3.58 & 25 & 7.8 \\
IPA Peja & 11.84 & 3.63 & 1.68 & 70.65 & 85.81 & 5.39 & 4.23 & 29 & 26 \\
\hline
\end{tabular}

On the analysis of the ready beer table no 4, we notice a rising bar of fermentation slightly larger than it should be, a larger alcohol amount compared to the standard beer, and more colors on the beer. (MEBAK 2014)

According to literature IPA Peja beer should have a value of the apparent rate of fermentation under $80 \%$, respectfully $74-78 \%$, but we have gained a beer with a higher percentage of visible fermentation instance, $85.81 \%$.

I hope that during the ongoing work if required by the market, will be able to produce high-value beer, set for IPA Peja beer.

\section{CONCLUSION}

After all these analyses and organoleptic testing that are made from the degustation group on "Birra Peja," we have concluded that IPA Peja beer fulfills all the needed conditions of a beer that can compete on the market.

- The brawn color is noticed, which makes the beer to be wanted an aromatic taste in banana and a slight bitterness.

- Also, the $\mathrm{CO}_{2}$ amount of $5.0 \mathrm{mg} / \mathrm{l}$ adds to the beer's freshness

- Also, with the analysis of the forcer test, we can use the IPA Peja beer for nine months without caring for it going bad.

- Specialty brewer's yeast was selected for its strong fermentation character, intensely fruity, and phenolic flavors - especially banana, clove, and peppery notes.

- The bitter is a bit stronger than the usual 29 compared to the standard beer, which is 22-24 EBC, also the color of the beer, standard beer has 7-9 units EBC, but IPA Peja beer has won a more noted color of $26 \mathrm{EBC}$. (Analytica 2018).

\section{REFERENCES}

Analytica, E. (2018). Colour of Beer: Spectrophotometric Method (IM). GetränkeFachverlag Hans Carl. https://dev.brewup.brewersofeurope.eu/ebc

Bamforth, C. (2010). The enzymology of cell wall breakdown during malting and mashing. An overview, Tech. Q. Mast. Brew. Assoc. Am. http://doi:10.1094/TQ47-1-0309-01

Barnes, Z. (2006). Brewing Process Control. Handbook of Brewing, edited by Fergus G. Priest and Graham G. Stewart. Boca Raton, Florida: CRC Press, Taylor \& Francis Group. https://doi.org/10.1201/9781420015171.ch11

Benitez, J. (1997). Hops and Hop Products, Manual of Good Practice. Nürenberg, Germany: Getränke-Fachverlag Hans Carl. http://doi:3418007589

Bonatto, D. (2021). The diversity of commercially available ale and lager yeast strains and the impac of brewer's preferential yeast choice on the fermentative beer $\begin{array}{llll}\text { profiles. Food Research } & \text { International, }\end{array}$ https://doi.org/10.1016/j.foodres.2021.110125

Charles, B. (2003). Beer: tap into the art and science of brewing. New York: Copyright (C) 2003 by Oxford University Press, Inc. https://doi.org/10.5860/choice.41-0326

EBC. (2008). Wort boiling and Clarification. European Brewery Convention. Manual of good practise. https://doi.org/3418007902

EBC. (2019). Manual of Good Practice Filtration and Stabilisation. European Convention of Breweries. https://doi.org/978-3-418-00856-1

Gonçalves Bortoleto, G., \& Pinheiro Claro Gomes, W. (2021, 01 12). Monitoring of organic volatile compounds in craft beers during fermentative process. Journal of Microbiology, Biotechnology and Food Sciences, n/a. https://doi.org/10.15414/jmbfs.4761

Hough, J., \& Brigs, D. (2004). Malting and Brewing Science. London: Academic Press, London. https://doi.org/10.1007/978-1-4615-1799-3

Kunze, W., \& Manger, H. (2004). Technology Brewing and Malting. Berlin: VLB https://9783921690499, 3921690498
Liguori, L., \& D- e Francesko, G. (2020). Characterization of the main physicochemical parameters in three styles of craft beer. IEEE International Workshop on Metorology for Agriculture and Forestry (MetroAgriFor), 314-318. http://10.1109/MetroAgriFor50201.9277673

López GM, Roche E, Rodríguez E. (2020). CONTAMINANT MICROBIOTA IN CRAFT BEERS. Journal of microbiology, biotechnology and food sciences, 9. https://doi.org/10.15414/jmbfs.2020.9.6.11811186

Loredana Liguori, G. d. (2021). Influence of malt composition on the quality of a top fermented beer. Journal food science technology, 2295-2303. https://doi.10.107/s13197-020-04740-8

MEBAK. (2014). Sensory Analysis: Collection of Brewing Analysis Methods of the Mitteleuropäischen Brautechnischen Analysenkommission. (F. Jacob, Ed.) Mebak. https://doi.9783981596045

MEBAK. (2017). Microbreweries: From Project Planning to Quality Assurance. Berlin: Mebak WienStephan. https://doi:9783981596069

Oghenetega L., Czipa N., Kovacs B., Alexa L. (2021, 08 01). Impact of the use of Gluten-free creals and spices on tihe quality parameters of beer. Journal of microbiology, biotechnology and food sciences, 11 https://doi.org/10.15414/jmbfs.3838

Zainasheff, J., \& White, C. (2010). Yeast: The Practical Guide to Beer Fermentation. Colorado: Brewers Publication. https://doi.9780937381960 